\title{
OPTIMASI ERMENTASI TEPUNG SINGKONG DAN APLIKASINYA PADA PEMBUATAN MAKANAN STIK
}

\begin{abstract}
Made Suladra ${ }^{1}$
ABSTRACT

The research was designed to determine the optimal fermentation time and the amount of cassava flour which can be used to produce sticks food crispy cassava flour. This research was done in two stages; The first stage, the optimization of fermentation used completely randomized design (CRD) with time at room temperature for fermentation; 1 day, 2 days 3 days and 4 days. The water content, total acid content and fiber content were analyzed. The second stage, cassava starch fermentation time selected was used for production of food sticks using a CRD with 4 treatments of cassava flour; $0 \%, 25 \%, 50 \%, 75 \%$. baking testing, moisture, reducing sugar, crude fiber content, and organoleptic tests were analyzed. Data were analyzed by using ANOVA and the differences among treatments were tested by the method Duncan's Multiple Ranges Test (DMRT) at the level of 5\%. The results showed shredded cassava fermentation by R. oryzae AT3 at room temperature for 3 days in a sealed plastic to produce cassava flour that have; the water content of $13.10 \%$, total acid $1.01 \%$, crude fiber $3.08 \%$, and white flour. Stick dough composition consisting of $50 \%$ flour and $50 \%$ of cassava starch fermented for 3 days were the best sticks food, preferred, and have organoleptic properties; crisp texture, light brown and slightly savory taste tasted cassava flour. Stick food with the addition of $50 \%$ cassava flour has a water content of $2.24 \%$, crude fiber of $2.23 \%$, reduced sugar of $2.27 \%$, and fried after baking of $77.50 \%$.
\end{abstract}

Keywords: R. oryzae AT3, cassava flour, stick food

\begin{abstract}
ABSTRAK
Penelitian ini bertujuan untuk mengetahui waktu fermentasi yang optimal dan jumlah tepung ketela (singkong) yang dapat digunakan untuk menghasilkan makanan stik tepung ketela yang renyah.Penelitian ini dilakukan dengan dua tahap; tahap pertama, optimalisasi waktu fermentasi menggunakan rancangan acak kelompokdengan waktu fermentasi pada suhu ruang selama ; 1 hari, 2 hari 3 hari, dan 4 hari. Dilakukan pengujian kadar air, kadar total asam dan kadar serat kasar.Tahap kedua, tepung singkong dengan waktu fermentasi terpilih digunakan untuk pembuatan makanan stik menggunakan rancangan acak kelompok dengan 4 perlakuan tepung ketela ; 0\%, 25 \%, 50\%, 75\%. Dilakukan pengujian pengembangan, kadar air, kadar gula reduksi, kadar serat kasar, dan uji organoleptik. Data dianalisis dengan teknik ANAVA dan adanya perbedaan diantara perlakuan diuji dengan metode Duncan`s Multiple Ranges Test (DMRT) pada jenjang 5\%.Hasil penelitian menunjukkan fermentasi ketela sawut dengan $R$. oryzae AT3 pada suhu ruang selama 3 hari dalam wadah plastik tertutup menghasilkan tepung ketela yang memiliki;kadar air 13,10\%, total asam 1,01\% (db), serat kasar 3,08\% (db), dan tepung berwarna putih. Komposisi adonan stik yang terdiri dari $50 \%$ tepung terigu dan $50 \%$ tepung ketela pohon yang difermentasi selama 3 hari menghasilkan makanan stik yang terbaik,disukai, dan memiliki sifat organoleptik; tekstur renyah, berwarna coklat muda dan cita rasa gurih agak terasa tepung ketela. Makanan stik dengan penambahan tepung ketela $50 \%$ mempunyai kadar air 2,24\%, serat kasar $2,23 \%(\mathrm{db})$, gula reduksi $2,27 \%(\mathrm{db})$, danpengembangansetelah digoreng sebesar $77,50 \%$.
\end{abstract}

Keyword: $R$. oryzae AT3, tepung singkong, makanan stik

\section{Pendahuluan}

Stik merupakan makanan ringan (snack food) yang bersifat kering, renyah (crispy) berbentuk batang memanjang dengan ukuran $1 \mathrm{x}$ $10 \mathrm{~cm}$ dan ketebalan $3 \mathrm{~mm}$. Makanan stik merupakan bahan makanan yang terbuat dari tepung gandum yang telah mengalami pengulian, pemipihan/penipisan adonan, pengecilan ukuran dan penggorengan. Produk makanan stik sudah dikenal dan digemari oleh masyarakat, dan disajikan dalam berbagai bentuk kemasan. Stik umumnya dibuat darti tepung terigu, tetapi dalam perkembangannya dapat dilakukan diversifikasi atau substitusi tepung terigu dengan jenis tepung lainnya yang berpotensi sebagai pengganti tepung terigu antara lain tepung singkong dalam bentuk MOCAF.

\footnotetext{
${ }^{1}$ Program Studi Teknologi Pangan Fakultas Teknologi Pertanian Universitas Widya Mataram Yogyakarta \e_madesuladra@yahoo.com
} 
MOCAF adalah tepung yang dibuat dari singkong melalui proses fermentasi oleh bakteri alami yang diawali dengan pengupasan kulit, dicuci, pengecilan ukuran, difermentasi, dikeringkan dan digiling. Jenis bakteri alami yang berperan dalam proses fermentasi adalah bakteri asam laktat (BAL). Bakteri asam lakttat tersebut berperan terhadap perubahan karakteristik singkong, karena adanya produksi asam laktat, enzim spesifik, dan senyawa aromatis (Camargo dkk., 1988; Demiate dkk., 2000; Marcon dkk., 2006).

Pembuatan tepung singkong di Nigeria yang disebut dengan nama Lafun, Lafun dibuat dengan cara pengupasan, pemotongan ubi kayu (casava), kemudian direndam selama 3-5 hari (Moorthy dan Mathew, 1998). Proses pembuatan Lafu juga dapat dilakukan dengan modifikasi memarut casava segar dan difermentasi dengan menggunakan inokulum murni Corynobacterium manihot dan Geotrium candida. Setelah proses fermentasi, casava parut dikempa dengan screw press pada tekanan tertentu untuk mengurangi kadar air, kemudian dikeringkan (Nwabueze dan Odunsi, 2007).

Subagio, (2006) juga melaporkan bahwa mikrobia yang tumbuh pada singkong akan menghasilkan enzim proteolitik dan selulotik yang dapat menghancurkan dinding sel singkong sedemikian rupa sehingga terjadi pembebasan granula pati. Proses pembebasan pati ini akan menyebabkan perubahan karakteristik dari tepung yang dihasilkan berupa; naiknya viskositas, kemampuan gelatinisasi, daya dehidrasi, dan kemudahan melarut. Granula pati akan mengalami hidrolisis dan menghasilkan monosakarida sebagai bahan baku untuk produksi asam-asamorganik.

Pada proses fermentasi secara alami pada pembuatan tepung singkong mengalami kesulitan dalam hal pengendalian proses perendaman dalam air sumur selama fermentasi karena mudah terkontaminasi oleh bakteri lainnya. Disamping itu, proses pengeringan pada pembuatan MOCAF secara tradisional memerlukan waktu yang cukup lama dan cenderung terjadi kontaminasi selama pengeringan. Oleh karena itu, perlu dilakukan penelitian dengancara(diparut kasar) tanpa perendaman. Fermentasi singkong disawut menggunakan jamur $R$. oryzae, karena $R$. oryzae bersifat non- toksis,mampu memproduksi asam laktatdan tumbuh pada aktivitas air/Aw yang lebih rendah dari bakteri asam laktat.
Menurut
Bramorski

(1998), mikroorganisme yang mempunyai kemampuan memperbaiki sifat organoleptik substrat padat hasil pertanian secara sempurna mensintesa komponen volatile. Rhizopus oryzae selama proses fermentasi makanan menghasilkan miselia yang mampu menekan pertumbuhan bakteri kontaminan. Pertumbuhan optimal $R$. oryzae pada rentang nilai $\mathrm{pH} 3,4-6$, namun produksi asam laktat oleh $R$. oryzae ini bekerja optimal pada pH netral (Davies dkk., dalam Tanege dkk., 1999). Produk asam laktat yang timbula selama fermentasi akan menyebabkan semakin banyaknya senyawa pati terurai menjadi molekul yang lebih sederhana, sehingga tepung yang dihasilkan akan memilikinilai cerna yang lebih baik, serta dapat dimanfaatkan sebagai bahan dasar pembuatan makanan stik tepung singkong.

Singkong atau ubi kayu (Manihot utilisima)merupakan sumber karbohidrat yang baik dan mudah diperoleh dengan harga murah. Perkembangan Teknologi Pangan menunjukkan bahwa singkong yang direndam dalam suspensi biakan Bakteri Asam Laktat (BAL) dan dapat dibuat tepung yang disebut Modified Cassava Flour (MOCAF). Namun kelemahannya bahwa proses pengeringan MOCAF terlalu lama dan berpeluang terjadi kontaminasi yang cukup tinggi oleh bakteri lain yang tidak dikehendak. Oleh karena itu, pemanfaatan $R$. oryzae dalam proses pembuatan MOCAF dengan sistem ubi kayu disawut akan memperepat proses pengeringan.

Waktu fermentasi terlalu lama, menyebabkan $R$. oryzae akan membentuk sporaspora yang berwarna hitam. Spora-spora $R$. oryzae berwarna hitam menyebabkan sifat fisik tepung singkong yang dihasilkan akan berwarna hitam dan berbau tidak sedap. Oleh karena perlu dilakukan optimalisasi waktu fermentasi, agar dihasilkan tepung singkong dengan sifat fisik; 
warna putih, dan pengembangan yang baik, serta dapat dimanfaatkan sebagai makanan stik.

\section{Metode penelitian}

\section{Tempat Penelitian, bahan dan alat.}

Penelitian dilakukan di Laboratorium Pangan dan Gizi Fakultas Teknologi Pertanian Universitas Widya Mataram Yogyakarta.Bahan yang digunakann adalah Singkong (ubi kayu) diperoleh dari pasar Telo Karang Kajen Yogyakarta, R. oryzaeAT3 Lab. Mikrobiologi FTP-UGM, dan bahan kimia lainnya berupa Potato Dextrose Agar (PDA).

\section{Prosedur penelitian}

\section{Pembuatan starter}

Beras sebanyak $100 \mathrm{~g}$ setelah dicusi bersih ditambahkan $50 \mathrm{ml}$ larutan $0,1 \%$ asam laktan dan dipanaskan hingga larutan terserap semua ke dalam beras. Kemudian disterilkan, didinginkan hingga mencapai suhu $40{ }^{\circ} \mathrm{C}$ dan diinokulasi dengan suspensi spora $R$. oryzae AT3. Media difermentasikan pada suhu kamar selama 7 hari hingga spora berwarna hitam, dikeringkan, dan digiling supayamenjadi tepung.

\section{Pembuatan tepung singkong pada berbagai waktu fermentasi.}

Singkong dikupas kulitnya, dicuci bersih, disawut, dan direndam dengan perbandingan air (1:1) selama 30 menit untuk menghilangkan sebagian asam sianida dalam singkong. Setelah direndam kemudian ditiriskan dan dijemur di bawah sinar matahari selama 2 jam. Sawut singkong kering sebanyak $500 \mathrm{~g}$ ditambahkan CaCO3 $0,5 \%$ dan diinokulasi dengan starter $R$. oryzae AT3 masing-masing sebanyak $1 \%$, kemudian masukan ke dalam wadah dan difermentasikan dalam rak fermentasi pada suhu $28^{0} \mathrm{C}, \mathrm{RH} 96 \%$ selama : 1 hari, 2 hari, 3 hari, 4hari.Singkong sawut telah terfermentasi selama 1 hari, 2 hari, 3 hari, dan 4 hari tersebut dikeringkan selama 3 hari di bawah sinar matahari, digiling dan diayak dengan ukuran diameter saringan 80 mesh. Tepung singkong dilakukan analisis; kadar air, total asam, dan kadar serat.

\section{Pembuatan Stik dari tepung singkong terpilih}

Tepung ketela terpilih, tepung terigu, dan bahan- bahan pendukung lainnya dibuat adonan stik dengan komposisi seperti Tabel 1 berikut: . Tabel 1. Komposisi Adonan Makanan Stik

\begin{tabular}{|llccc|}
\hline \multirow{2}{*}{ Komponen } & \multicolumn{4}{c}{ Komposisi Adonan Makanan Stik } \\
\cline { 2 - 5 } & $\mathrm{T} 0$ & $\mathrm{~T} 25$ & $\mathrm{~T} 50$ & $\mathrm{~T} 75$ \\
\hline $\begin{array}{l}\text { Tepung } \\
\text { singkong }\end{array}$ & 0 & 100 & 200 & 300 \\
$\begin{array}{l}\text { Tepung } \\
\text { terigu (g) }\end{array}$ & 400 & 300 & 200 & 100 \\
Garam (g) & 5 & 5 & 5 & 5 \\
$\begin{array}{l}\text { Kuning } \\
\text { telur (g) }\end{array}$ & 10 & 10 & 10 & 10 \\
$\begin{array}{l}\text { Sode Kue } \\
\text { (g) }\end{array}$ & 5 & 5 & 5 & 5 \\
Margarin & 40 & 40 & 40 & 40 \\
Air (ml) & 120 & 120 & 120 & 120 \\
\hline
\end{tabular}

Pada Tabel 1 masing-masing bahan adonan ditimbangkemudian dilakukan pengulian sampai di peroleh adonan yang elastis, lunak dan halus (kalis). Adonan yang sudah kalis ditipiskan/dipipihkan dengan alat gilingan sampai diperoleh ketebalan $\pm 3 \mathrm{~mm}$, dilakukan pemotongan dengan ukuran panjang $10 \mathrm{~cm}$ lebar 0,5 cm. Makanan stik mentah dari masingmasing perlakuan kemudian digoreng hingga berwarna coklat kekuningan dan dilakukan pengujian organoleptik (Kartika,dkk,1988) meliputi: citarasa, warna, kerenyahan dan kesukaan. Uji kimia (Slamet, dkk.,1984) meliputi:kadar air, total asam, kadar serat, danuji pengembangan.

\section{Hasil dan pembahasan}

\section{Hasil analisis kimia tepung ketela pada berbagai waktu fermentasi.}

Ketela sawut tanpa fermentasi dan yang difermentasi selama 1 hari, 2 hari, 3 hari dan 4 hari dikeringkan di bawah sinar matahari selama 2 hari. Ketela sawut kering ditepung dan diayak ukuran 80 mesh, dan hasil masing-masing perlakuan dapat disajikan pada Gambar 1.

Pada Gambar 1 terlihat bahwa perlakuan berbagai waktu fermentasi memperlihatkan adanya perbedaan warna tepung yang dihasilkan. Fermentasi selama 4 hari miselia jamur $R$. oryzae AT3 telah berubah menjadi spora-spora berwarna 
hitam sehingga warna tepung menjadi lebih hitam. Derajat warna putih tepung yang dihasilkan dengan waktu fermentasi hari ke-4 berbeda nyata dari derajat warna putih tepung pada fermentasi hari ke-0 (kontrol), dan warna tepung yang agak kehitaman tidak memenuhi persyaratan mutu tepung singkong SNII 01-2997-1992 (Anonim,1992).

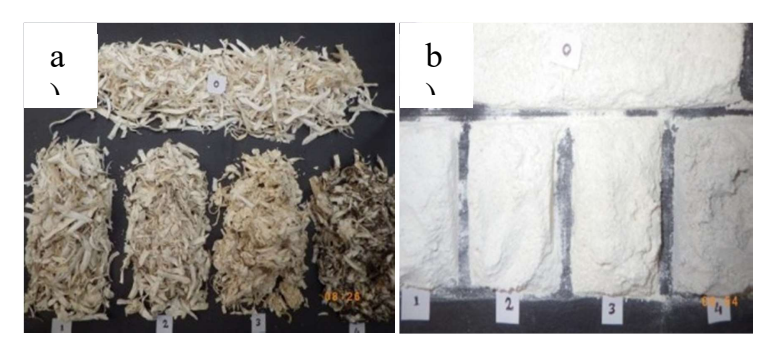

Gambar 1.Tepung Ketela fermentasi sampai hari ke-4. ( $a=$ ketela sawut terfermentasi kering; $b$ : tepung ketela terfermentasi; $0=$ hari ke- $0 ; 1=$ hari ke-1; $2=$ hari ke-2; $3=$ hari ke-3; 4= hari ke-4)

Tepung ketela dari berbagai waktu fermentasi dilakukan analisis : kadar air, kadar total asam, kadar serat kasar, dan pengembangan. Hasil analisis kimia dapat dilihat pada Tabel 2.

Tabel 2. Analisis Kimia tepung ketela terfermentasi

\begin{tabular}{l|l|l|l}
\hline $\begin{array}{l}\text { Perlakuan } \\
\text { Waktu } \\
\text { Fermentasi }\end{array}$ & $\begin{array}{l}\text { Kadar Air } \\
(\%)\end{array}$ & $\begin{array}{l}\text { Kadar Asam } \\
\text { Total (\%) }\end{array}$ & $\begin{array}{l}\text { Kadar Serat } \\
\text { Kasar (\%) }\end{array}$ \\
\hline Hari ke-0 & 10,43 & $0,12^{\mathrm{f}}$ & $2,09^{\mathrm{h}}$ \\
Hari ke-1 & 10,86 & $0,17^{\mathrm{f}}$ & $2,34^{\mathrm{h}}$ \\
Hari ke- 2 & 12,46 & $0,45^{\mathrm{f}}$ & $2,68^{\mathrm{g}}$ \\
Hari ke- 3 & 13,10 & $1,01^{\mathrm{e}}$ & $3,08^{\mathrm{g}}$ \\
Hari ke-4 & 13,51 & $3,24^{\mathrm{d}}$ & $3,05^{\mathrm{g}}$ \\
\hline
\end{tabular}

Keterangan: Rerata yang diikuti huruf yang berbeda menunjukkan antar perlakuan berbeda nyata pada taraf sigifikansi $5 \%$.

\section{KadarAir}

Hasil analisis dan uji statistik kadar air pada taraf signifikansi $5 \%$ pada Tabel 3 menunjukkan bahwa ada perbedaan nyata kadar air tepung ketela diantara perlakuan waktu fermentasi. Perlakuan fermentasi hari ke-0 dan hari ke- 1 tidak menunjukkan perbedaan nyata, karena pertumbuhan $R$. oryzae AT3 pada hari ke-1 berada pada fase adaptasi kefase pertumbuhan logaritmit, sehingga belum membentuk miselia yang kompak dan proses perombakan makromolekul belum berlangsung optimal.

Kadar air tepung hasil fermentasi $R$. oryzae AT3 pada hari ke-2 dan hari ke-3, terjadi kenaikkan kadar air yang signifikan masingmasing; $12,46 \%$ dan 13,06 \%. Kenaikan kadar air selama proses fermentasi akibat dari aktivitas $R$. oryzae AT3 yang merubah senyawa senyawa karbohidrat menjadi gula sederhana dan molekul air. Semakin lama waktu fermentasi, pertumbuhan miselia yang semakin kompak dipermukaan singkong sawut sehingga menyebabkan kadar air bahan menjadi lebih tinggi. Kadar air tepung ketela pada fermentasi hari ke-2, hari ke-3, dan hari ke-4 memiliki kadar air lebih tinggi dari syarat mutu tepung singkong SNII 01-2997-1992 (Anonim, 1992).

\section{Kadar total asam}

Total asam tertitrasi merupakan asam yang terdapat dalam singkong yang dihasilkan selama proses fermentasi yaitu pemecahan senyawa karbohidrat oleh ensim yang diproduksi oleh $R$. oryzae AT3. Asam laktat merupakan asam organik yang dominan dihasilkan dalam proses permentasi oleh $R$. oryzae AT3 dan dapat menyebabkan terjadinya penurunan $\mathrm{pH}$ bahan (Kurniawan, dkk., 2014). Pada Tabel 3 terlihat semakin lama waktu fermetasi kadar total asam terus meningkat secara signifikan pada taraf uji signifikansi $5 \%$ dengan nilai masing-masing: $0,12 \% ; 0,17 \% ; 0,45 \% ; 1,01 \%$; dan 3,24\%.

Kadar total asam pada fermentasi ketela sawut hari ke-1 dan hari ke-2 tidak menunjukkan adanya perbedaan yang nyata dengan perlakuan kontrol (hari ke-0), hal ini karena $R$. oryzae AT3 berada dalam fase pertumbuhan dan mulai timbulnya panas dipermukaan ketela sawut dan mulai terjadi perombakan senyawa-senyawa sederhanamenjadi asam-asam organik.Produksi asam organik terjadi setelah melewati fase pertumbuhan dan fase stasioner dan dihasilkan berbagai metabolit-metabolit sekunder berupa asam-asam organik dan beberapa senyawalainnya.

Kadar total asam ketela sawut pada feremntasi hari ke- 3 dan hari ke-4 terjadi 
kenaikan total asam yang signifikan dari fermentasi hari ke-1 dan hari ke-2. Kadar total asam ketela sawut pada fermentasi hari ke-4 sebesar $3,24 \% \quad \mathrm{~d} / \mathrm{b}$ tidak layak digunakan sebagai bahan baku pembuatan makanan stik, karena kadar total asam melampaui persyaratan Mutu Tepung Singkong SNII 01-2997-1992 (Anonim,1992).

\section{Kadar serat kasar}

Pada Tabel 3 terlihat kadar serat kasar tidak larut air mengalami peningkatan secara signifikan hingga fermentasi hari ke-4 berturutturut; $2,09 \% ; 2,34 \% ; 2,68 \% ; 3,08 \% ; 3,05 \%$. Fermentasi hari ke-1 tidak menunjukkan peningkatan perbedaan yang nyata dengan perlakuan kontrol (hari ke-0).Fermentasi hari ke2, hari ke-3, dan hari ke-4 menunjukkan peningkatan yang signifikan dengan perlakuan kontrol (hari ke- 0). Peningkatan kadar serat kasar selama fermentasi disebabkan oleh jumlah miselia dan spora $R$. oryzae AT3 semakin kompak dan semakin banyak. Komponen penyusun miselia ataupun spora $R$. oryzaeAT3 tersebut dapat disusun oleh senyawa-senyawa polisakarida dan senyawa lainnya yang bersifat tidak larut dalam air.

\section{Uji organoleptik dan sifat kimia makanan stik tepung ketelaterfermentasi.}

Stik merupakan makanan ringan (snack food) yang bersifat kering, renyah (crispy) berbentuk batang memanjang dengan ukuran $0,5 \mathrm{~cm} \times 10$ $\mathrm{cm}$ dan ketebalan $3 \mathrm{~mm}$. Formulasi makanan stik pada berbagai perbandingan tepung terigu dan tepung ketela terfermentasi selama 3 hari (Gambar 2), selanjutnya dilakukan uji organoleptik dan sifat kimia formulasi terpilih.

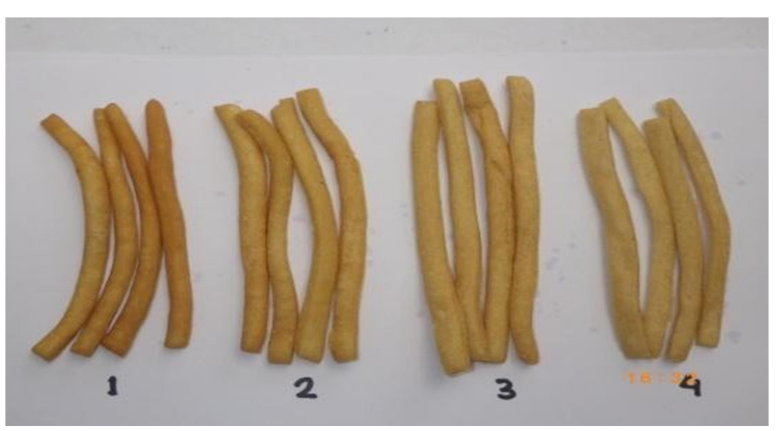

Gambar 2. Makanan Stik pada berbagai formulasi tepung ketela terfermentasi 3 hari $(1=$ tepung terigu $100 \% ; 2=$ tepung terigu $75 \%$ dan tepung ketela $25 \%$; $3=$ tepung terigu $50 \%$ dan tepung ketela $50 \%$; $4=$ tepung terigu $25 \%$ dan tepung ketela $75 \%$ ).

\section{Cita rasa}

Cita rasa makanan stik pada berbagai penambahan tepung ketela terfermentasi pada Tabel 3 menunjukkan adanya perbedaan nyata diantara perlakuan. Komposisitepung ketela terfementasi semakin besar dalam makanan stik memberikan cita rasa tepung terigu berkurang dan cita rasa tepung ketela semakinmeningkat.

Perlakuan dengan penambahan tepung ketela 25 $\%$ (T25) dan penambahan tepung ketela $50 \%$ (T50) tidak memberikan pengaruh yang nyata terhadap cita rasa tepung ketela yaitu dengan skor 2,73 dan 3,15. Cita rasa tepung ketela semakin meningkat dan berbeda nyata pada perlakuan penambahan tepung ketela sebanyak75 \% (T75) dengan skor 3,65 yaitu cita rasa dominan terasa tepung ketela terfermentasi dari pada cita rasa tepung terigu.

Cita rasa adalah kumpulan dari senyawasenyawa yang bersifat larut dalam pelarut organik. Cita rasa gurih pada tepung ketela terfermentasi sangat spesifik yang disebabkan oleh adanya senyawa-senyawa tertentu sebagai hasil perombakan karbohidrat, protein, lemak oleh aktifitas $R$. oryzae AT3 selama fermentasi, sehingga penambahan $75 \%$ tepung ketela terfermentasi masih memberikan kesan cita rasa gurih.

\section{Warna}

Warna makanan stik merupakan parameter mutu yang spesifik terhadap kesan, dan warna pada pengolahan pangan dapat muncul akibat adanya reaksi-reaksi kimia dan fisis dalam bahan pangan.Hasil pengujian mutu warna makanan stik pada Tabel 3 menunjukkan, bahwa semakin banyak penambahan tepung ketela terfermentasi dalam adonan menyebabkan perbedaan yang nyata terhadap warna makanan stik yang dihasilkan. Warna makanan stik dengan penambahan tepung ketela $75 \%$ (T75) dan $50 \%$ 
(T50) memberikan kesan warna berbeda nyata dengan skor 2,23 (coklat muda) dan 2,81 (coklat muda agak kuning) dan berbeda nyata pla dengan kontrol tepung terigu $100 \%$ (T00) yang berwarna agak coklat (skor 1,50). Semakin banyak penambahan tepung ketela menyebabkan warna coklat semakin berkurang dan mengarah ke warna coklat muda agak kuning (skor2,81).

Warna coklat yang muncul selama pengolahan pangan dengan suhu tinggi atau penggorengan adalah warna yang disebabkan oleh reaksi-reaksi antara gugus amino dan gugus gula reduksi melalui jalur reaksi Maillard. Penambahan tepung ketela semakin besar menyebabkan jumlah gugus amino semakin dala bahan semakin berkurang karena kadar protein tepung ketela lebih rendah dari protein tepung terigu, sehingga warna coklat akan berkurang.

\section{Kerenyahan}

Kerenyahan dan tekstur pada tingkat tertentu merupakan salah satu syarat yang Tabel 3. Uji Organoleptik Makanan Stik

\begin{tabular}{|c|c|c|c|c|c|}
\hline \multirow[t]{2}{*}{ Tipe Uji } & \multicolumn{4}{|c|}{$\begin{array}{l}\text { Perbandingan tepung ketela dan } \\
\text { tepung terigu dalam adonan }\end{array}$} & \multirow[t]{2}{*}{ Keterangan skor tipe uji } \\
\hline & $\mathrm{T}_{00}$ & $\mathrm{~T}_{25}$ & T50 & $\mathrm{T}_{75}$ & \\
\hline Cita rasa & $1,46^{\mathrm{a}}$ & $2,73^{b}$ & $3,15^{b}$ & $3,65^{\mathrm{c}}$ & $\begin{array}{l}1=\text { Gurih, tidak terasa tepung ketela } \\
2=\text { Gurih agak terasa tepung ketela } \\
3=\text { Gurih cukup terasa tepung ketela } \\
4=\text { Gurih terasa tepung ketela } \\
5=\text { Gurih sangat terasa tepung ketela }\end{array}$ \\
\hline Kerenyahan & $3,19^{\mathrm{d}}$ & $2,27^{\mathrm{e}}$ & $2,04^{\mathrm{e}}$ & $2,46^{\mathrm{e}}$ & $\begin{array}{l}1=\text { Sangat renyah } \\
2=\text { Renyah } \\
3=\text { Agak renyah } \\
4=\text { Kurang renyah } \\
5=\text { Tidak renyah }\end{array}$ \\
\hline Warna & $1,5^{\mathrm{h}}$ & $1,96^{\mathrm{f}}$ & $2,23^{\mathrm{g}}$ & $2,81^{\mathrm{g}}$ & $\begin{array}{l}1=\text { Coklat } \\
2=\text { Coklat muda } \\
3=\text { Coklat muda agak kuning }\end{array}$ \\
\hline Kesukaan & $2,27^{\mathrm{k}}$ & $2,15^{\mathrm{k}}$ & $2,42^{\mathrm{k}}$ & $3,38^{\mathrm{j}}$ & $\begin{array}{l}1=\text { Sangat diterima } \\
2=\text { Diterima } \\
3=\text { Agak diterima } \\
4=\text { Tidak diterima } \\
5=\text { Sangat tidak diterima }\end{array}$ \\
\hline
\end{tabular}

Keterangan: Rerata yang diikuti huruf yang berbeda menunjukkan antar perlakuan berbeda nyata pada taraf sigifikansi $5 \%$.

\section{Kesukaan}

Tingkat kesukaan yang diberikan adalah tingkat kesukaan keseluruhan terhadap makanan stik yang dihasilkan yaitu meliputi penting pada makanan stik.Makanan stik yang tidak renyah dan tekstur yang terlalu keras tidak disukai oleh konsumen. Hasil uji organoleptik terhadap kerenyahan stik pada Tabel 3 menunjukkan ada perbedaan yang nyata terhadap kerenyahan makanan stik yang dihasilkan.

Kerenyahan makanan stik dengan penambahan tepung ketela $25 \%$ (T25) dan penambahan tepung ketela $50 \quad \% \quad$ (T50) memberikan kesan kerenyahan yang lebih baik dan beda nyata dengan perlakuan kontrol yaitu tepung terigu $100 \%$ (T00) dengan skor 3,19 (agak renyah). Subsitusi dengan penambahan tepung ketela $75 \%($ T75) masih memberikan kesan renyah dengan skor 2,46 yang tidak beda nyata dengan perlakuan (T75) dan (T50) yang memiliki skor 2,27 (renyah) dan 2,04(renyah). Sifat kerenyahan pada makanan kering sangat dipengaruhi oleh kecepatan keluarnya gas dan penguapan air selama pemanasan. 
kesukaan panelis pada perlakuan penambahan tepung ketela terfermentasi sebanyak $25 \%$ dengan skor 2,15 (diterima) dan $50 \%$ dengan skor 2,42 (diterima) tidak ada beda nyata dengan perlakuan kontrol dengan skor 2,27 ( diterima). Skor tingkat kesukaan atau penerimaa panelis pada perlakuan penambahan tepung ketela terfermentasi $75 \%$ (T75) masih dapat diterima oleh panelis dengan skor 3,38 agak tidak diterima. Perlakuan penambahan $75 \%$ tepung ketela terfermentasi menyebabkan terjadi penurunan derajat penerimaan stik dari skor diterima menjadi skor agak diterima, karena kesan cita rasa tepung ketela lebih dominan dan kekokohan tekstur lebih mudah patah. Hal ini disebabkan rendahnya kadar gluten dalam adonan yang berfungsi untuk membentuk adonan elastis dan rongga-rongga udara saat penggorengan.

Makanan stik tepung ketela terfermentasi yang dipilih adalah perlakuan penambahan $50 \%$ tepung ketela terfermentasi (T50), karena panelis masih dapat menerima dengan baik dan tidak beda nyata dengan tingkat kesukaan dengan perlakuan kontrol yaitu makanan stik tepung terigu tanpa penambahan tepung ketela terfermentasi.

\section{Analisis KimiaStik tepung singkong terpilih yang disukai.}

Makanan stik yang dihasilkan dari tepung ketela terfermentasi selama 3 hari dengan perbandingan $50 \%$ tepung singkong dan $50 \%$ tepung terigu dilakukan pengujian sifat kimia dan sifat pengembangan seperti disajikan pada Tabel 4.

Tabel 4. Hasil analisis kimia dan pengembangan makanan stik

\begin{tabular}{lcccc}
\hline \multirow{2}{*}{$\begin{array}{c}\text { Campuran } \\
\text { Tepung } \\
\begin{array}{c}\text { (Terigu: } \\
\text { Ketela) }(\mathrm{g})\end{array}\end{array}$} & $\begin{array}{l}\text { Kadar } \\
\text { air } \\
(\%)\end{array}$ & $\begin{array}{l}\text { Kadar } \\
\text { serat } \\
\text { kasar } \\
(\%)\end{array}$ & $\begin{array}{l}\text { Kadar } \\
\text { gula } \\
\text { reduksi } \\
(\%)\end{array}$ & $\begin{array}{l}\text { Pengemb } \\
\text { angan } \\
(\% \mathrm{v} / \mathrm{v})\end{array}$ \\
\hline $\begin{array}{l}\text { T00 } \\
(\text { Kontrol })\end{array}$ & 2,75 & 0,96 & 1,25 & 51,67 \\
\hline $\begin{array}{l}\text { T50 ( T200 } \\
\text { K200) }\end{array}$ & 2,24 & 2,23 & 2,27 & 77,5 \\
\hline
\end{tabular}

Keterangan: Rerata yang diikuti huruf yang berbeda menunjukkan antar perlakuan berbeda nyata pada taraf sigifikansi $5 \%$.
Hasil analisis kadar air pada Tabel 4 terlihat bahwa makanan stik yang dihasilkan memiliki kadar air 2,24 \% dan terjadi pernurunan dari kontrol stik tepung terigu. Hal ini karena makanan stik memiliki kadar serat $2,23 \%$ dan protein gluten yang lebih rendah dalam adonan menyebabkan kemampuan mengikat air menjadi lebih lemah, sehingga selama penggorengan molekul air lebih mudah menguap. Makanan stik dengan kadar air 2,24\% yang tergolong makanan kering masih memenuhi standar mutu seperti yang dipersyaratkan SNI untuk makanan kering dengankadar air maksimal 4 \% (BSN , 2000).

Makanan stik tepung ketela memiliki kadar serat kasar 2,23\% meningkat 1,17\% dibandingkan dengan stik tepung terigu. Kenaikan kadar serat disebabkan adanya penambahan tepung ketela yang difermentasi 3 hari memiliki kadar serat kasar $3.08 \%$ pada Tabel 2.Kadar serat sangat bermanfaat bagi kesehatan untuk memperlancar air besar karena serat pangan dapat memperbesar volume feces.

Kadar gula reduksi dan volume pengembangan pada makanan stik tepung ketela juga mengalami peningkatan dibandingkan dengan makanan stik tepung terigu tanpa penambahan tepung ketela. Kenaikan kadar gula reduksi sebagai akibat terjadi hasil perombakan senyawa pati dalam ketela sawut selama fermentasi 3 hari. Gula reduksi yang merupakan mikromolekul dari senyawa pati, memiliki nilai cerna yang tinggi sebagai sumber energi.

\section{Kesimpulan}

Waktu fermentasi yang optimal pada ketela sawut dengan $R$. oryzae AT3 pada suhu ruang adalah selama 3 har, dan tepung ketela yang dihasilkan memiliki; kadar air kadar air $13,10 \%$, kadar total asam $1,01 \%$, kadar serat kasar 3,08 \%, dan berwarna putih.Makanan stik yang dibuat dari adonan yang terdiri dari $50 \%$ tepung ketela dan $50 \%$ tepung terigu menghasilkan makanan stik masih disukai dan memiliki sifat; tekstur renyah, berwarna coklat muda dan cita rasa gurih agak terasa tepung 
ketela.Makanan stik yang dihasilkan mempunyai sifat kimia; kadar air 2,24 \%; kadar serat kasar $2,23 \%$; kadar gula reduksi 2,27 \%, dan pengembangan setelah digoreng sebesar 77,50 $\%$.

\section{Daftar pustaka}

Anonim, 1992. Standar Nasional Indonesia. Badan Standarisasi Nasional.LIPI; Jakarta. Akindahunsi, A.A, Oboh, G, Oshodi.A.A. 1999. Effect of Fermenting Cassava With Rhyzopus oryzae On The Chemical Compotition of It's Flour and Gari Product. United Nations Educations Scientific and Cultural Organization and International Atomic Energy Agency. 26.

Bramorski,A.Christen,P.Ramirez,M.Soccol,C.R.

Revah,S.1998. Productions of Volatile Compound by Fungus R.oryzae. Biotechnology (20):4

Camargo,C. Colona, P. Buleon, A. dan Molard, D.R. 1988. Fuctional Properties of Sour Cassava (Manihot utilisima) Starch: Polvilho Azedo."Journal of The Science of Food and Agriculture 81:429-435.

Kartika B. Puji Hastuti dan W. Supartono, 1998, Pedoman Uji Inderawi Bahan Pangan, PAU Pangan dan Gizi, UGM, Yogyakarta. Morthy SN, dan Mathew G. 1998. Cassava Fermentation and Associated Changes in Physicochemical and Functional Properties. Crit., Rev. Food Sci.Nutr. (38): 73- 121.

Nwabueze,T.U., dan Odunsi,F.O. 2007. Optimations of Process Condotions for Cassava (Manihot esculenta) Lafun Production. African Journal of Biotechnology 6(5): 603-61.

Slamet Sudarmaji, Bambang Haryono, dan Suhardi, 1984, Prosedur Analisa Untuk Bahan Makanan dan Pertanian, Liberty, Yogyakarta.

Subagio, A. 2006. Ubi Kayu: Substitusi berbagai Tepung-Tepungan. Food Review, April 2006;18-22.

Tanege, M. Dupuis, I. Kuhlemeier,C. 1999. Ethanolic Fermentation: New Fuctions for an Old Pathway. Elservier Science.(4):8 